\title{
FAKTOR-FAKTOR YANG MEMPENGARUHI KEBIJAKAN UTANG PERUSAHAAN MANUFAKTUR DI BURSA EFEK INDONESIA
}

\author{
Thio Lie Sha \\ Fakultas Ekonomi Universias Tarumanagara \\ Email: thioliesha@yahoo.com
}

\begin{abstract}
This study aims to obtain empirical evidence on the influence of Profitability, Tangibility Asset, Tax rate, Firm Growth and Firm Size in manufacturing companies listed on the Indonesia Stock Exchange during 2014-2016. Tests using SPSS 24.0 and purposive sampling method. Data used in this study were 174 companies. The result of $t$ test shows that Profitability has negative effect and significant to Debt policy, Firm size has positive influence and significant to Debt policy while Tangibility asset, Tax rate, Firm growth do not have significant influence to Debt policy, and the result of F test are Profitability, Tangibility asset,Tax rate, Firm growth and Firm size are simultans influence on Debt policy.
\end{abstract}

Keywords: Profitability, Tangibility asset ,Tax rate, Firm growth and Firm size and Debt polic

Abstrak: Penelitian ini bertujuan untuk mendapatkan bukti empiris mengenai pengaruh Profitabilitas, Tangibility asset, Tax rate, Pertumbuhan perusahaan dan Ukuran Perusahaan terhadap Kebijakan utang pada perusahaan manufaktur yang terdaftar di Bursa Efek Indonesia selama tahun 2014-2016. Pengujian menggunakan SPSS 24.0 dan metodepuposive sampling. Data yang diambil berjumlah 174 perusahaan.Hasil uji $\mathrm{t}$ menunjukkan bahwa Profitabilitas berpengaruh negatif dan signifikan terhadap Kebijakan utang, Ukuran perusahaan memiliki pengaruh positif dan signifikan terhadap Kebijakan utang sedangkan Tangibility asset, Tax rate, Pertumbuhan perusahaan tidak berpengaruh signifikan terhadap Kebijakan utangdan hasil uji $\mathrm{F}$ menunjukkan bahwa Profitabilitas, Tangibility asset, Tax rate, Pertumbuhan perusahaan dan Ukuran perusahaan secara bersama berpengaruh signifikan terhadap Kebijakan utang.

Kata kunci: Profitabilitas, Tangibility asset, Tax rate, Pertumbuhan perusahaan dan Ukuran perusahaan, Kebijakan utang.

\section{PENDAHULUAN}

Perkembangan ekonomi dunia menyebabkan perusahaan harus mampu mengontrol struktur pendanaan agar dapat bersaing dengan perusahaan lain. Perusahaan lebih hati-hati dan kreatif dalam memperoleh sumber pendaanaan yang efektif.Kebijakan Utang memiliki peranan penting dalam rangka memperoleh sumber pendanaan dari eksternal perusahaan. Manajer keuangan harus mampu memperoleh pendanaan bagi perusahaan secara efisien sehingga dapat meminimalkan biaya modal yang ditanggung oleh perusahaan. Kebijakan utang biasanya lebih aman daripada menerbitkan saham karena dapat digunakan sebagai alat pengawasan terhadap manajemen agar bekerja sesuai dengan tujuan perusahaan 
sehingga mengurangi risiko kebangkrutan. Faktor yang mempengaruhi kebijakan utang antara lain dipengaruhi Profitabilitas, Tangible asset, Tax Rate, Pertumbuhan perusahaan dan Ukuran perusahaan.

Profitabilitas merupakan hubungan antara pendapatan dan beban yang dihasilkan dari penggunaan aset perusahaan dalam kegiatan produktif. Laba yang besar akan menarik minat investor untuk menanamkan modal dan ikut bekerja sama serta mempermudah kreditur untuk memberikan pinjaman kepada perusahaan. Penelitian Bambang Sidaytno dan Septavia Mustika sari (2013), Mahmud Muslim (2015), Ahadiyah Muslida Dewi yuniarti (2013) Yeniatie dan Nicken Destriana (2010), Rosela Selvilita Geovana (2015) Farah Margaretta (2014)membuktikan bahwa profitabilitas berpengaruh negatif signifikan terhadap Kebijakan Utang. Namun berbeda dengan Steven Yap, Hendra (2016), Pancawati hardiningsih dan Rachmawati Meita Oktaviani (2012), Yeniatie dan Nicken Destriana (2010) profitabilitas tidak memiliki pengaruh terhadap Kebijakan Utang.

Tangible assetmerupakan Aset tetap untuk mendukung operasional perusahaan dalam memperoleh keuntungan. Struktur aktiva tetap yang tinggi dapat memperluas investasi perusahaan dan mempermudah perusahaan untuk memperoleh pinjaman dana. Penelitian Mahmud Muslim (2015), Ahadiyah Muslida Dewi yuniarti (2013)Tangibility Asset berpengaruh positif tidak signifikan terhadap Kebijakan Utang. Namun berbeda dengan penelitian Farah Margaretta (2014), Steven Yap Hendra (2016), Pancawati hardiningsih dan Rachmawati Meita Oktaviani (2012), Bambang Sidaytno dan Septavia Mustika sari (2013), Soraya Meiryanan Permanasari (2017), Hendra (2014), Yeniatie dan Nicken Destriana (2010), Steven dan Lina (2011) Tangibility Asset berpengaruh positif signifikan terhadap Kebijakan Utang. Salah satu persyaratan pinjaman utang adalah adanya Aktiva tetap berwujud dijadikan jaminan kredit.

Tax Rate merupakan suatu penetapan pajak yang dibuat pemerintah untuk menghitung dan menentukan jumlah pajak yang harus dibayar dan di pungut oleh wajib pajak. Memilih pendanaan perusahaan melalui utang, bunga yang dibayarkan kepada pemberi pinjaman merupakan biaya yang dapat di kurangkan atas laba usaha.Penelitian Farah Margareta (2014)Tax Rate berpengaruh positif tidak signifikan terhadap Kebijakan Utang. Namun berbeda dengan penelitian Rosela Selvilita Geovana (2015) Tax Rate berpengaruh positif signifikan terhadap Kebijakan Utang. Penggunaan utang maka bunga yang dibayarkan dapat dikurangkan atas laba usaha sehingga berhubungan dengan beban pajak.

Tingkat pertumbuhan perusahaan yang tinggi cenderung akan memerlukan dana yang besar untuk mengembangkan usahanya. Untuk kebutuhan dana tersebut manajemen akan mengambil keputusan menggunakan utang, karena memberikan penghematan biaya dibandingkan dengan biaya penerbitan saham. Penelitian Steven dan Lina (2011) dan Mahmud Muslim(2015) menyatakan pertumbuhan perusahaan berpengaruh positif tidak signifkan terhadap Kebijakan Utang. Namun berbeda dengan penelitian Farah Margareta (2014), Pancawati hardiningsih dan Rachmawati Meita Oktaviani (2012), berpengaruh negatif signifikan terhadapan Kebijakan Utang; Penelitian Steven Yap (2016), Bambang Sidaytno dan Septavia Mustika sari (2013), Soraya Meiryanan Permanasari (2017), Hendra (2014), Yeniatie dan Nicken Destriana (2010) berpengaruh positif signifikan terhadap Kebijakan Utang. Hal ini karena tidak semua perusahaan yang mempunyai 
tingkat pertumbuhan yang tinggi memilih utang sebagai sumber pendanaan, bisa dari dana internal atau menerbitkan saham.

Ukuran perusahaan yang lebih besar memiliki akses yang lebih besar untuk mendapat sumber pendanaan,sehingga memperoleh krediturpun akan lebih mudah karena perusahaan dengan ukuran besar memiliki profitabilitas lebih besar. Penelitian Steven Yap (2016), Bambang Sidaytno dan Septavia Mustika sari (2013), Soraya Meiryana Permanasari (2017), Hendra (2014)menyatakan ukuran perusahan berpengaruh positif signifikan terhadap Kebijakan Utang. Tidak sama dengan penelitianFarah Margareta (2014), Steven dan lina (2011) berpengaruh positif tidak signifikan terhadap Kebijakan Utang; Penelitian Mahmud Muslim (2015) berpengaruh negatif tidak signifikan. Ukuran Perusahaan semakin besar sehingga penjualan semakin tinggi maka semakin banyak perputaran uang maka perusahan lebih mudah mendapatkan pinjaman dana dalam bentuk utang.

\section{KAJIAN TEORI}

Agency theory adalah untuk menyelaraskan kepentingan prinsipal dan agen dalam hal terjadi konflik kepentingan. Teori keagenan sebagai hubungan antara agen (manajemen/ pengelola) dan principal (kepemilikan). Di dalam hubungan keagenan terdapat suatu kontrak dimana satu orang atau lebih (principal) memerintah orang lain (agen) untuk melakukan suatu jasa atas nama prinsipal dan memberi wewenang kepada agen untuk membuat keputusan yang terbaik bagi prinsipal (Masdupi, 2005). Salah satu kendala yang muncul antara agent dan principal adalah adanya asimetri informasi (information asymmetry). Menurut Rahmawati, Suparno dan Qomariyah (2006) asimetri informasi adalah suatu keadaan dimana agent mempunyai informasi lebih banyak tentang perusahaan dan prospek di masa mendatang dibandingkan dengan principal, memberikan kesempatan kepada agent menggunakan informasi untuk memanipulasi pelaporan keuangan sebagai usaha memaksimalkan kemakmuran sendiri. Asimetri informasi ini mengakibatkan terjadinya moral hazard berupa usaha manajemen untuk melakukan earnings management (Rahmawati, dkk., 2006). Menurut Oyong (2012), terdapat dua macam asimetri informasi yaitu Adverse selection dan Moral Hazard. Adverse selection yaitu suatu keadaan dimana principle tidak dapat mengetahui apakah suatu keputusan diambil oleh agen benar-benar didasarkan atas informasi yang telah diperolehnya atau terjadi sebuah kelalaian dalam tugas. Moral hazard adalah permasalahan yang muncul jika agen tidak melakukan hal-hal yang disepakati bersama dalam kontrak kerja.

Agency Relationship menurut Ross,Westerfield, dan Jordan (2010: 10) mengemukakan bahwaThe relationship between stockholders and management is called agency relationship. Such a relationship exists whenever someone (the principal) hires another (the agent) to represent his or her interests.

Agency Cost menurutGodfrey et al. (2010) menjelaskan biaya agensi merupakan setara dolar pengurangan kesejahteraan yang dialami oleh karena perbedaan mendasar dari pokok dan kepentingan agen. Jensen dan Meckling membagi agency cost menjadi biaya pemantauan, biaya ikatan, dan biaya sisa. Agency conflictmenurut Harjito dan Nurfauziah, (2006) dapat terjadi karena timbul informasi tidak simetri antara pemegang saham dan manajer. Munculnya informasi tidak simetri dan konflik kepentingan antara mereka 
dipertimbangkan sebagai sumber yang sangat penting bagi ketidakefisienan dalam proses pembuatan keputusan.

Pecking order Theorymenurut Gitman dan Zutter (2012: 534) menyatakan bahwa: "Pecking order meaning a hierarchy of financing that begins with retained earnings, which is followed by debt financing and finally external equity financing" menjelaskan ketika manajemen ingin mendanai sebuah proyek baru, mereka akan menggunakan laba di tahan terlebih dahulu, jika pendanaan internal tidak mencukupi, maka manajer akan membutuhkan dana eksternal seperti utang.

Trade off theory menyatakan perusahaan lebih menyukai pendanaan dari luar daripada melakukan internal financing, terutama bagi perusahaan yang memiliki penghasilan kena pajak yang tinggi dan aset yang banyak. Menurut Sari (2012) menjelaskan "suatu perusahaan mempunyai tingkat utang yang optimal dan berusaha untuk menyesuaikan tingkat utang ke arah titik optimal tersebut ketika perusahaan berada pada tingkat utang yang terlalu tinggi (overlevered) atau terlalu rendah (underlevered)". Titik optimal ini terjadi karena adanya pajak, yaitu sebagai faktor yang mendorong perusahaan untuk meningkatkan utangnya. Trade off theory lebih menyangkut ke strategi atau tujuan finansial jangka panjang.

Kebijakan Utangmerupakansumber pendanaan external, digunakan untuk membiayai kegiatan operasional perusahaan. Pengambilan keputusan penggunaan sumber dana dari utang harus dipertimbangkan mengenai besarnya bunga yang ditimbulkan dari utang tersebut berdasarkan Surya dan Rahayuningsih (2012). Menurut Gitman dan Zutter (2012: h.508) "Leverage refers to the effects that fixed-cost have on returns that shareholders earn". Leverage diukur dengan menggunakan debt ratio.Debt ratio merupakan rasio untuk mengukur seberapa besar jumlah aktiva perusahaan yang dibiayai dengan utang.

Profitabilitasmenurut Fahmi (2011) ukuran efektivitas manajemen secara keseluruhan yangditujukan oleh besar kecilnya tingkat keuntungan yang diperoleh dalam hubungannya dengan penjualan maupuninvestasi. Semakin baik profitabilita semakin baik menggambarkan kemampuan tingginya perolehankeuntungan perusahaan.

Tangible Asset menurut Kieso, Weygandt dan Warfield (2011) adalah "a resource controlled by the entity as a result of past events and from which future economic benefits are expected to flow to the entity". Asset merupakan sumber daya yang dikuasai oleh perusahaan sebagai akibat dari peristiwa masa lalu dan manfaat ekonomi di masa depan diharapkan akan diperoleh perusahaan. Sedangkan Brigham dan Houston (2015:188) "Tangibility is a guarantee of a company whose assets are adequate to be used as collateral in the use of debt. "Common assets that can be used by many firms can be good guarantees, while not for assets with a specific purpose".

Tax ratemenurut Yap Steven, (2016) "Pajak merupakan iuran rakyat kepada kas negara berdasarkan undang-undang dengan tidak mendapat jasa timbal yang langsung dapat ditunjukkan dan yang digunakan untuk membayar pengeluaran umum".Sedangkan Hendra (2014) Tax rate merupakan kontribusi yang harus dibayarkan kepada pemerintah, baik secara pribadi maupun badan usaha yang telah terdaftar.

Pertumbuhan Perusahaan menurut Yeniatie dan Destriana (2010) mengemukakan Tingkat pertumbuhan yang semakin cepat mengidentifikasikan bahwa perusahaan sedang mengalami ekspansi. Hal ini menyebabkan timbulnya kebutuhan dana yang besar. Maka perusahaan menggunakan berbagai cara untuk memenuhi kebutuhan dana tersebut. 
Ukuran perusahaanmenurut Yap Steven (2016)gambaran besar kecilnya suatu perusahaan yang didapat dari total asset/penjualan dari suatu perusahan. Semakin besar penjualan maka semakin besar pula suatu perusahaan. Semakin banyak penjualan maka semakin banyak perputaran uang dalam perusahaan.

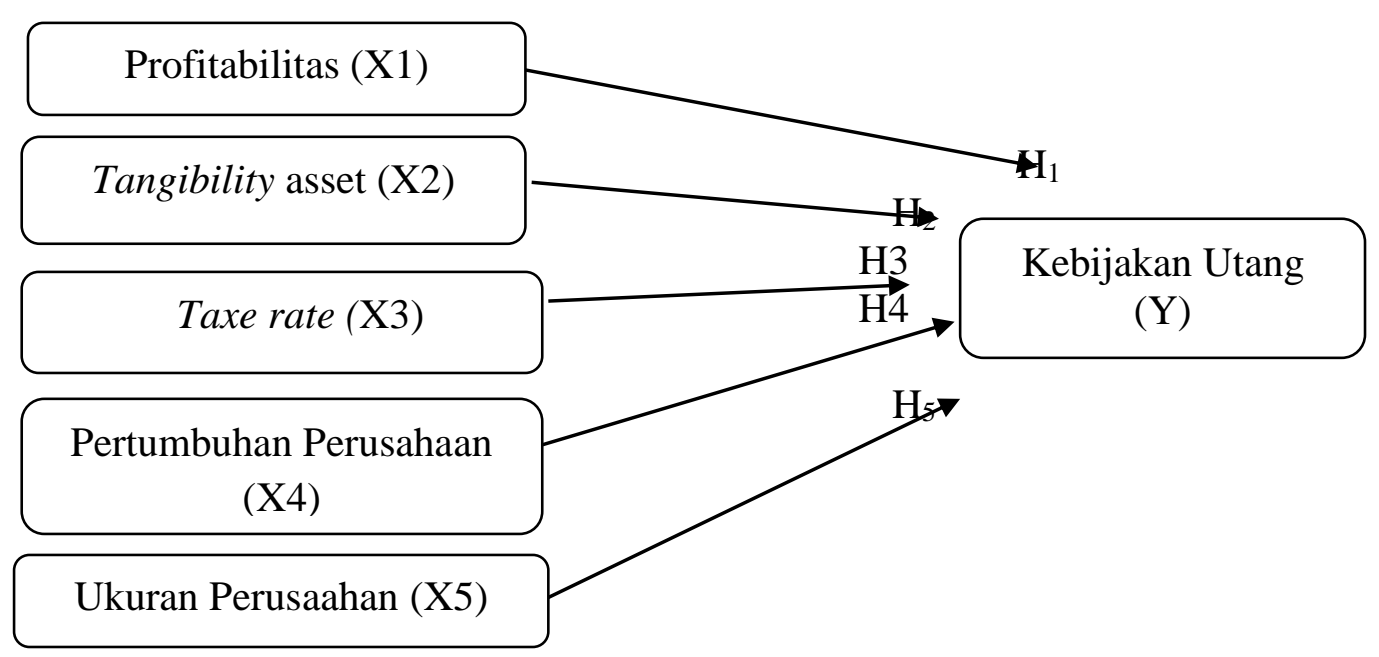

Gambar 1. Kerangka Pemikiran dan Hipotesis

Berdasarkan uraian yang telah dipaparkan, maka hipotesis dalam penelitian ini adalah sebagai berikut:

$\begin{array}{ll}\mathrm{H}_{1} & \begin{array}{l}\text { Profitabilitas berpengaruh negatifdan signifikan terhadap } \\ \text { nilai Kebijakan Utang }\end{array} \\ \mathrm{H}_{2} & \begin{array}{l}\text { Tanggibility of assetberpengaruh positif dan tidak } \\ \text { signifikan terhadap Kebijakan Utang }\end{array} \\ \mathrm{H}_{3} & \begin{array}{l}\text { Taxe rateberpengaruh positif dan tidak signifikan terhadap } \\ \text { Kebijakan Utang }\end{array} \\ \mathrm{H}_{4} & \begin{array}{l}\text { Pertumbuhan Perusahaan berpengaruh positif dan tidak } \\ \text { signifikan terhadap Kebijakan Utang }\end{array} \\ & \text { Ukuran Perusahaan berpengaruh positif dan signifikan } \\ \mathrm{H}_{5} & \text { terhadap Kebijakan Utang }\end{array}$

\section{METODE}

Desain penelitian menggunakan konsklusif deskriptif yaitu bertujuan untuk menguji hipotesis dan hubungan variabel-variabel berdasarkan sampel data yang di ambil dan data yang dihasilkan dianalisis secara kuantitatif. Populasi dalam penelitian ini adalah perusahaan manufaktur yang terdaftar di BEI pada periode 2014-2016. Total perusahaan 
manufaktur 144 dan kemudian di pilih berdasarkan kriteria yang ditentukan.Metode pemilihan sampel menggunakanpurposive sampling dengankriteria: Perusahaan Manufaktur yang terdaftar di BEI pada periode 2014-2016, yang secara konsisten terdaftar di BEI pada tahun 2014-2016 dan laporan keuangan dalam mata uang Rupiah serta tidak mengalami kerugian pada tahun 2014-2016.

Operasionalisasi Variabel. Variabel Dependenadalah Kebijakan Utang menggunakan rumus leverage menunjukan seberapa besar kebutuhan pendanaan yang dibiayai oleh utang dengan menggunakan asset. Menurut Margareta (2014) adalah:

$$
\text { Leverage }=\frac{\text { Total Debt }}{\text { Total Asset }}
$$

Variabel Independen yang digunakan terdiri dari 5 variabel yaitu:

Profitabilitas menunjukan seberapa besar laba yang dihasilkan dari penggunaan aset dalam aktivitas produksi. Rumus menurut Margareta (2014) adalah:

Profitabilitas $=\frac{\text { NetIncome }}{\text { TotalAsset }}$

TangibilityAssetmenunjukan seberapa besar aktiva tetap yang ada dalam keseluruhan total aktiva yang dimiliki perusahan. Rumus menurut Hendra (2014) adalah:

Tangibility asset $=\frac{\text { Fixed Assets }}{\text { Total Assets }}$

Tax rate menunjukan seberapa besar pajak yang dikenakan pada perusahan yang dilihat dari laba penghasilan dengan laba sebelum pajak.Rumusmenurut Margaretha (2014) adalah:

$$
\text { Tax Rate }=\frac{\text { Income Tax }}{\text { Earnings Before tax }}
$$

Pertumbuhan Perusahaan menunjukan gambaran kinerja perusahaan yang dicapai dalam melakukan investasi dengan membandingkan periode saat ini dengan periode sebelumnya.Rumus menurut Margareta (2014) adalah:

Pertumbuhan perusahaan $=\frac{\text { Total Asset }_{t}-\text { Total Asset }_{t-1}}{\text { Total Asset }_{t-1}}$

Dimana, $\mathrm{TA}_{t}$ : total aktiva tahun berjalan

$\mathrm{TA}_{\mathrm{t}-1}$ : total aktiva tahun sebelumnya.

Ukuran perusahan menunjukan gambaran perusahaan untuk mecapai keberhasilan yang dapat tercemin dari penjualan dari suatu perusahaan. Rumus menurut Yap Steven (2016) adalah:

\section{Ukuran Perusahaan $=$ Natural log of sales.}

Teknik Pengumpulan data menggunakan data sekunder, yang di peroleh dari BEI dan siitus www.idx.co.id berupa laporan keuangan perusahaan manufakur periode 2014-2016. Diolah menggunakanSPSS24. Dilakukan analisis statisticdengan uji statistik deskriptif,uji asumsi klasik dan analisis regresi linear berganda. 
Uji Statistik Deskriptif. Nenurut Ghozali (2016) memberikan gambaran atau deskripsi dari nilai rata-rata (mean), standar deviasi, varian, maksimum, minimum, sum, range, kurtosis dan skewness atau kemencengan distribusi.

Uji Asumsi Klasikterdiri dari:

a. Uji Normalitas menurut Ghozali (2016),apakah dalam model regresi, variabel pengganggu atau residual memiliki distribusinormal. Menggunakan grafik normal $P-P$ plot of Regession Standardized Residual dan One-Sample Kolmogorov-Smirnov Test. Uji statistik non-parametrik Kolomogrov-Smirnov (K-S) dilakukan dengan membuat hipotesis (Ghozali, 2016). Jika nilai Asymp, Sig (2-tailed) $\geq$ alpha $(\alpha=0.05)$ maka data terdisribusi normal.

b. Uji Multikolinieritas menurut Ghozali (2016: h.103),apakah model regresi yang ditemukan adanya korelasi antar variabel independen. Model Regresi yang baik tidak terjadi korelasi antara variabel independen. Multikolinieritas dilihat dari 1) nilai tolerance dan2) Variance Inflation Factor (VIF). Jika VIF $\leq 10$ dan nilai tolerance $\geq 0,10$ maka tidak terjadi multikolinieritas.

c. Uji Autokorelasi menurutSinggih (2015: h.192), apakah model regresi linier ada korelasi kesalahan penggangu pada periode sekarang dan periode sebelumnya. Jika terjadi korelasi, maka dinamakan ada problem autokorelasi.Ujiini menggunakan D-W (Durbin-Watson), di nyatakan lolos jika: 1) Angka D-W dibawah -2 berarti ada autokorelasi positif, 2) Angka D-W di antara -2 sampai 2 tidak ada autokerelasi, 3) Angka D-W diatas 2 ada autokorelasi negatif.

d. Uji Heteroskedastisitasmenurut Ghozali (2016: h.134), apakah dalam model regresi terjadi ketidaksamaan variance dari residual satu pengamatan ke pengamatan yang lain.Jika variance dari residual satu pengamatan ke pengamatan lain tetap, maka disebut Homoskedastisitas.Model yang baik adalah yang Homoskedastisita.Menggunakan Uji Glejser. Jika signifikan > 0,05 maka tidak terdapat heteroskedatisitas.

\section{Uji Hipotesis}

a. Pengujian hipotesis menggunakan analisis regresi berganda. Model regresi adalah sebagai berikut: $Y=\alpha+b_{1} x_{1}+b_{2} x_{2}+b_{3} x_{3}+b_{4} x_{4}+b_{5} x_{5}+\varepsilon$

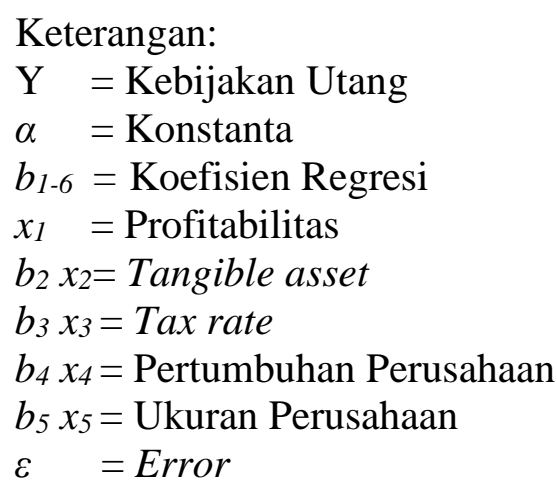

b. Uji Koefisien Determinasi (adjusted $\mathrm{R}^{2}$ ) menurut Ghozali (2016: h.171) digunakan untuk menguji goodness-fit dari model regresi. Nilai koefisien determinasi $=0$ maka 
variasi dari variabel dependen tidak dapat diterangkan oleh variabel independen sama sekali. Sementara bila koefisien determinasi $=1$ maka variasi dari variabel dependen secara keseluruhan dapat diterangkan oleh variabel independen. Adjusted $\mathrm{R}^{2}$ mempunyai nilai antara nol sampai satu.

c. Uji F menurut Ghozali (2016: h.171),semua variabel independen yang dimasukkan dalam model mempunyai pengaruh secara bersama-sama terhadap variabel dependen. Hasil ujiF Sig<0.05 maka ada pengaruh signifikan dari semuavariable independent secara bersama terhadap variabel dependen.

d. Uji t menurut Ghozali (2016: h. 171), untuk mengetahui pengaruh masing-masing variabel independen terhadap variabel dependen. Apabila sig $\mathrm{t}<0,05$ maka terdapat hubungan yang signifikan antara variabel independen dengan variabel dependen secara parsial.

\section{HASIL DAN PEMBAHASAN}

Tabel 1. Prosedur Pemilihan Sampel Penelitian

\begin{tabular}{lcc}
\hline \multicolumn{1}{c}{ Kriteria } & $\begin{array}{c}\text { Jumlah } \\
\text { Perusahaan }\end{array}$ & $\begin{array}{c}\text { Jumlah } \\
\text { Data }\end{array}$ \\
\hline $\begin{array}{l}\text { Perusahaan Manufaktur yang terdapat di BEI pada tahun } \\
\text { 2014-2016 }\end{array}$ & 144 & 432 \\
$\begin{array}{l}\text { Perusahaan Manufaktur yang tidak konsisten terdaftar di BEI } \\
\text { pada tahun 2014 - 2016 }\end{array}$ & $(23)$ & $(69)$ \\
$\begin{array}{l}\text { Perusahaan Manufaktur yang memakai kurs US Dollar dalam } \\
\text { laporan keuangan pada tahun 2014-2016 }\end{array}$ & $(18)$ & $(54)$ \\
$\begin{array}{l}\text { Perusahaan Manufaktur yang mengalami kerugian pada } \\
\text { tahun 2014-2016 }\end{array}$ & $(45)$ & $(135)$ \\
Jumlah sampel penelitian & 58 & 174 \\
\hline
\end{tabular}

Sumber: Hasil Pengolahan Sampel

Terdapat 58 sampel perusahaan yang memenuhi kriteria dan total 174 data dari laporan keuangan perusahaan manufaktur tahun 2014-2016 yang terdaftar di BEI dan www.idx.co.id. Setelah itu dilakukan uji statistik deskriptif, uji asumsi klasik, dan uji hipotesis.Uji asumsi klasik terdiri dari uji normalitas, uji multikolinearitas, uji autokorelasi dan uji heteroskedastisitas.Objek penelitian adalah Kebijakan utang, Profitabilitas, Tangible asset, Tax rate, Pertumbuhan perusahaan dan Ukuran perusahaan. Berikut hasil uji statistik deskriptif.

Pada Tabel 2 Data sebanyak 174 data meliputi Profitabilitas, Tangibility Asset, Tax rate, Pertumbuhan perusahaan, dan Ukuran Perusahaan. Nilai minimum dan maksimum menunjukkan nilai terendah dan nilai tertinggi dari variabel Profitabilitas, Tangibility Asset, Tax rate, Pertumbuhan perusahaan, dan Ukuran Perusahaan. Mean menunjukkan rata-rata untuk masing-masing variabel Profitabilitas, Tangibility Asset, Tax rate, Pertumbuhan perusahaan, dan Ukuran Perusahaan. 
Tabel 2. Hasil Uji Statistik Deskriptif

Descriptive Statistics

\begin{tabular}{lccccr}
\hline & $\mathrm{N}$ & Minimum & Maximum & Mean & \multicolumn{1}{c}{ Std. Deviation } \\
\hline Kebijakan Utang & 174 & .0714586328 & .8387210155 & .3908076790 & .1717091057 \\
Profitabilitas & 174 & .0007571940 & .6701880342 & .0960644174 & .00955595531 \\
Tangibility Asset & 174 & .04027886857 & .8084987825 & .3570152818 & .1708953438 \\
Tax rate & 174 & .00290999798 & 5.548388912 & .3206852206 & .4234159102 \\
Pertumbuhan & 174 & -.143041286 & .9169162686 & .1156639076 & .1468814538 \\
perusahaan & & & & & \\
Ukuran Perusahaan & 174 & 25.35262162 & 33.18772303 & 28.46227937 & 1.737943699 \\
Valid N (listwise) & 174 & & & & \\
\hline
\end{tabular}

Sumber: Hasil Pengolahan Data SPSS ver. 24.0

Standar devias mengukur seberapa banyak penyebaran nilai data dari nilai rataratanya (mean). Semakin tinggi standar deviasi suatu variabel, maka semakin menyebar/menyimpang data dalam variabel tersebut.

Variabel Kebijakan Utang: nilai rata-rata 0.3908076790 , standar deviasi 0.1717091057, Nilai minimum 0.714586328 dan nilai maksimum 0.8387210155. Angka minimumPT. Semen Indonesia Tbk tahun 2014 angka maksimumPT. Jemblo Cable Company Tbk tahun 2014; Variabel Profitabilitas: nilai rata-rata 0.0960644174,standar deviasi0.0955595531, Nilai minimum 0.0007571940 dan nilai maksimum 0.6701880342 . Angka minimumPT. Indospring Tbk tahun 2015., angka maksimum PT. Star Petrochem Tbk tahun 2016; Variabel Tangibility Asset : nilai rata-rata 0.3570152818, standar deviasi 0.1708953438 ,Nilai minimum 0.04027886857 dan nilai maksimum 0.8084987825 . Angka minimum PT Duta Pertiwi Nusantara Tbk tahun 2016 ,angka maksimum PT. Semen Indonesia Tbk tahun 2016; Variabel Tax Rate : nilai rata-rata 0,3206852206, standar deviasi 0.4234159102, Nilai minimum 0.0290999798 dan nilai maksimum 5.548388912. Angka minimum PT. Intan Wijaya Internasonal Tbk tahun 2014 , angka maksimum PT. Indo Acidatama Tbk tahun 2016; Variabel Pertumbuhan Perusahaan: nilai rata-rata 0.1156639076, standar deviasi 0.1468814538. Nilai minimum-.143041286, nilai maksimum 0.9169162686. Angka minimum PT. Jemblo Cable Company Tbk tahun 2014,angka maksimum PT. Taishcal Indonesia Tbk tahun 2014; Variabel Ukuran Perusahaan : nilai rata-rata 28.46227937, standar deviasi 1.737943699 , Nilai minimum 25.35262162 dan nilai maksimum 33.18772303. Angka minimum PT. Nusantara Inticorpora Tbk tahun 2014, angka maksimumPT. Star Petrochem Tbk tahun 2015.

Hasil Uji Asumsi dan Analisis Data. Uji asumsi klasik: Uji normalitas menggunakan uji statistic non-parametric one-sample Kolmogorov-smirnov, Uji multikolinearitas dengan melihat nilai tolerance dan VIF, Uji heteroskedastisitas menggunakan uji glejser, dan Uji autokorelasi menggunakan durbin-watson test.

a.Uji normalitas bertujuan untuk menguji apakah dalam model regresi, variabel pengganggu atau residual memiliki distribusi normal atau tidak. 
Tabel 3. Hasil Uji Normalitas

One-Sample Kolmogorov-Smirnov Test

\begin{tabular}{llr}
\hline & & \multicolumn{2}{c}{ Unstandardized } \\
Residual
\end{tabular}

Sumber: Hasil Pengolahan Data SPSS ver. 24.0

Hasil pengujianAsymp. Sig.(2-tailed)0.200 > 0.05 menunjukkanundstandardized residual terdistribusi normal.

b.Uji Multikolinearitas untukmenguji korelasi antara variabel independen yang satu dengan variabelindependen yang lain. Regresi yang baik tidak mengandung korelasi di antara variabel independennya. Jika terjadi korelasi, berarti pada model regresi terjadi gejala multikolinearitas/tidak ortogonal. Menggunakan nilai tolerance dan VIFsebagai pengukur multikolinearitas. Jika nilai Tolerance $>0.10$ dan nilai $V I F<10$ maka tidak terjadi multikolinearitas.

Tabel 4. Hasil Uji Multikolinearitas

\begin{tabular}{llll}
\multicolumn{3}{c}{ Coefficients $^{\mathbf{a}}$} \\
\cline { 2 - 3 } Model & \multicolumn{3}{c}{ Collinearity Statistics } \\
\cline { 2 - 4 } (Constant) & Tolerance & \multicolumn{3}{c}{ VIF } \\
Profitabilitas & 0.896 & 1.116 \\
Tangibility Asset & 0.983 & 1.017 \\
Tax Rate & 0.994 & 1.006 \\
Pertumbuhan Perusahaan & 0.989 & 1.011 \\
Ukuran Perusahaan & 0.887 & 1.114 \\
\hline
\end{tabular}

a. Dependent Variable: Kebijakan Utang

Hasil pengujian multikolinearitas pada variabel Profitabilitas menunjukkan nilai tolerancer $0.896>0.10$ dan nilai VIF1.116 < 10.Nilai tolerance pada Tangibility Asset $0.983>0.10$ dan nilai VIF1.017 < 10. A. Nilai tolerance pada Tax Rate sebesar 0.994 atau $>0.10$ dan nilai VIF sebesar $1.006<10$.Nilai tolerance pada Pertumbuhan Perusahaan sebesar 0.989 atau $>0.10$ dan nilai $V I F$ sebesar $1.011<10$. Nilai tolerance pada Ukuran Perusahaan sebesar 0.887 atau $>0,10$ dan nilai VIF sebesar $1.114<10$. Kesimpulan tidak terdapat masalah multikolinearitas. 
c.Uji Autokorelasiuntuk menguji apakah dalam model regresi linear terdapat korelasi antara kesalahan pengganggu pada periode $\mathrm{t}$ dengan kesalahan pengganggu pada periode $\mathrm{t}-1$ (sebelumnya). Model regresi yang baik bebas dari autokorelasi, menggunakan uji Durbin Watson (DW Test), dengan tingat kepercayaan 95\% atau $\alpha=5 \%$.Dikatakan lolos uji autokorelasi jika memenuhi persyaratan nilai $D W$ test, yaitu: 1) nilai D-W dibawah -2 berarti diindikasikan ada autokorelasi positif, 2) nilai D-W di antara -2 sampai 2 berarti diindikasikan tidak ada autokerelasi, 3) nilai D-W diatas 2 berarti diindikasikan ada autokorelasi negatif..

Tabel 5. Uji Autokorelasi

Model Summary ${ }^{\mathrm{b}}$

\begin{tabular}{lrrrrr}
\hline Model & R & R Square & $\begin{array}{c}\text { Adjusted R } \\
\text { Square }\end{array}$ & $\begin{array}{c}\text { Std. Error of the } \\
\text { Estimate }\end{array}$ & Durbin-Watson \\
\hline 1 & $.392^{\mathrm{a}}$ & .154 & .129 & $\begin{array}{r}0.16026553700 \\
0000\end{array}$ & 0.767 \\
\hline
\end{tabular}

a. Predictors: (Constant), Ukuran Perusahaan, Tangibility Asset, Tax rate,

Pertumbuhan perusahaan, Profitabilitas,

b. Dependent Variable: Kebijakan Utang

Hasil uji autokorelasi dengan Durbin Waston sebesar 0.767, nilaidiantara -2 sampai dengan 2, maka disimpulkan tidak ada autokorelasi positif atau negatif.. d.Uji Heteroskedastisitasuntuk menguji apakah model regresi terjadi ketidaksamaan variance dari residual satu pengamatan ke pengamatan yang lain. Model regresi yang baik adalah tidak terdapat gejala heteroskedastisitas. Uji heteroskedastisitas dengan menggunakan Uji Gletser.

Tabel 6. Uji Heteroskedastisitas

Coefficients $^{\mathrm{a}}$

\begin{tabular}{lcrrrr}
\hline & \multicolumn{2}{c}{$\begin{array}{c}\text { Unstandardized } \\
\text { Coefficients }\end{array}$} & $\begin{array}{c}\text { Standardized } \\
\text { Coefficients }\end{array}$ & \multicolumn{1}{c}{$\mathrm{t}$} & \multicolumn{1}{c}{ Sig. } \\
\cline { 2 - 6 } \multicolumn{1}{c}{ Model } & \multicolumn{1}{c}{ B } & Std. Error & Beta & & \\
(Constant) & 0.291 & 0.127 & & 2.292 & 0.023 \\
Profitabilitas & 0.009 & 0.081 & 0.009 & -0.229 & 0.908 \\
Tangibility Asset & 0.029 & 0.043 & 0.051 & -0.001 & 0.509 \\
Tax Rate & 0.003 & 0.17 & 0.012 & 0.717 & 0.871 \\
Pertumbuhan Perusahaan & 0.46 & 0.50 & 0.070 & -1.329 & 0.363 \\
Ukuran Perusahaan & -0.06 & 0.004 & -116 & 0.507 & 0.152 \\
\hline
\end{tabular}

a. Dependent Variable: ABS_RES

Sumber: Hasil Pengelolaan Data SPSS ver. 24.0

Nilaisig. profitabilitas0.908 > 0.05,Nilai sig.Tangiblity Asset $0.509>0.05$.Nilai sig.Tax Rate $0.871>0.05$. Nilai sig.Pertumbuhaan Perusahaan $0.363>0.05$. Nilai sig.Ukuran Perusahaan 0.152>0.05. Kesimpulkan tidak terdapat masalah Heteroskedastisitas. 
Hasil Analisis Data menggunakan uji koefisien korelasi berganda (R), uji koefisien determinasi (Uji Adjusted R2), uji bersama (uji F), dan uji signifikansi individual (uji t). Tingkat keyakinan sebesar 95\% atau tingkat signifikan 5\% .

Tabel 7. Hasil Analisis Regresi Berganda Coefficients $^{\mathrm{a}}$

\begin{tabular}{lrr}
\hline \multicolumn{1}{c}{ Model } & \multicolumn{2}{c}{ Unstandardized Coefficients } \\
(Constant) & B & Std. Error \\
\hline Profitabilitas & -0.297 & 0.210 \\
Tangibility Asset & -0.607 & 0.135 \\
Tax Rate & 0.095 & 0.072 \\
Pertumbuhan Perusahaan & 0.040 & 0.029 \\
Ukuran Perusahaan & 0.104 & 0.083 \\
& 0.024 & 0.007 \\
\hline
\end{tabular}

a. Dependent Variable: Kebijakan Utang

Sumber: Hasil Pengelolaan Data SPSS ver. 24.0

Hasil analiaiaregresi linear berganda:Kebijakan Utang $=-0.297-0.607$ Perusahaan + 0.024 Ukuran Perusahaan $+\varepsilon$. Nilai $\alpha$ sebesar -0.297 , menunjukkan apabila nilai Profitabilitas, Tangibility Asset, Tax rate, Pertumbuhan Perusahaan dan Ukuran perusahaan adalah 0 maka Kebijakan Utangi sebesar -0.297.

Apabila Profitabilitas naik sebesar satu satuan, maka menurunkan Kebijakan Utang sebesar 0.607 satuan, dengan asumsi variabel independen Tangibility Asset, Tax rate, Pertumbuhan Perusahaan dan Ukuran perusahaan dianggap konstan, dan sebaliknya.; Apabila Tangibility Asssetnaik sebesar satu satuan, maka akan meningkatkan Kebijakan Utang sebesar 0.095 satuan, dengan asumsi variabel independen Profitabilitas,Tax rate, Pertumbuhan Perusahaan dan Ukuran perusahaan dianggap konstan dan sebaliknya.; Apabila Tax Rate naik sebesar satu satuan, maka akan meningkatkan Kebijakan Utang sebesar 0.040 satuan, dengan asumsi variabel independen Profitabilitas, Tangibility Asset, Pertumbuhan Perusahaan dan Ukuran perusahaan dianggap konstan dan sebaliknya. ; Apabila Pertumbuhan Perusahaannaik sebesar satu satuan, maka akan meningkatkan Kebijakan Utang sebesar 0.104 satuan, dengan asumsi variabel independen Profitabilitas, Tangibility Asset, Tax rate dan Ukuran perusahaan dianggap konstan dan sebaliknya.; Apabila Ukuran Perusahaan naik sebesar satu satuan, maka akan meningkatkan Kebijakan Utang sebesar 0.024 satuan, dengan asumsi variabel independen lain yaitu Profitabilitas, Tangibility Asset, Tax rate dan Pertumbuhan perusahaan dianggap konstan dan sebaliknya.

Hasil Uji t Apabila tingkat signifikansi< 0.05 maka variabel independen secara parsial berpengaruh signifikan terhadap variabel dependen.

Tabel 8. Profitabilitas: menunjukkan nilai signifikansi $0.000<0.05$. Nilai B -0.607 . Menunjukkan Profitabilitas berpengaruh negatif signifikan terhadap Kebijakan utang. ;Tangibility Asset:menunjukkan nilai signifikansi 0.187>0.05. Nilai B 0.095. Menunjukan Tangibility Asset berpengaruh positif tidak signifikan terhadap Kebijakan Utang.; Tax Rate: menunjukkan nilai signifikansi 0.171>0.05. Nilai B 0.040 . 
Tabel 8. Hasil Uji t

\begin{tabular}{lcccc}
\multicolumn{5}{c}{ Coefficients $^{\mathrm{a}}$} \\
\cline { 2 - 5 } \multicolumn{1}{c}{ Model } & \multicolumn{2}{c}{$\begin{array}{c}\text { Unstandardized } \\
\text { Coefficients }\end{array}$} & $\mathrm{t}$ & Sig. \\
\cline { 2 - 5 } B & Std. Error & & \\
\hline Profitabilitas & -0.297 & 0.210 & -1.415 & 0.159 \\
Tangibility Asset & -0.607 & 0.135 & -4.503 & 0.000 \\
Tax Rate & 0.095 & 0.072 & 1.325 & 0.187 \\
Pertumbuhan Perusahaan & 0.040 & 0.029 & 1.376 & 0.171 \\
1 Ukuran Perusahaan & 0.104 & 0.083 & 1.249 & 0.213 \\
\hline
\end{tabular}

a. Dependent Variabel: Kebijakan Utang

Sumber: Hasil Pengolahan Data SPSS ver. 24.0

MenunjukkanTax Rate berpengaruh positif tidak signifikan terhadap Kebijakan Utang.; Pertumbuhan Perusahaan: menunjukkan nilai signifikansi 0.213>0.05. Nilai B 0.104 . Menunjukkan Pertumbuhan Perusahaan berpengaruh positif tidak signifikan terhadap Kebijakan Utang.; Ukuran Perusahaan: menunjukkan nilai signifikansi $0.001<0.05$. Nilai B 0.024. Menunjukkan variabel tingkat Ukuran Perusahaan berpengaruh positif dan signifikan terhadap Kebikan Utang.

Hasil Uji F: menguji semua variabel independen terhadap variabel dependen secara bersama. Apabila nilai signifikansi $\mathrm{F}<0.05$ variabel independen secara bersama-sama berpengaruh signifikan terhadap variabel dependen.

Tabel 9. Hasil Uji F

ANOVA $^{\mathrm{a}}$

\begin{tabular}{llrrrrr}
\hline & & \multicolumn{2}{c}{ Sum of } & & & \\
& Model & Squares & Df & Mean Square & F & \multicolumn{1}{c}{ Sig. } \\
\hline 1 & Regression & 0.786 & 5 & 0.157 & 6.118 & $.000^{\mathrm{b}}$ \\
& Residual & 4.315 & 168 & 0.026 & & \\
& Total & 5.101 & 173 & & & \\
\hline
\end{tabular}

a. Dependent Variable: Kebijakan Utang

b. Predictors: (Constant), Ukuran Perusahaan, Tax Rate, Pertumbuhan

Perusahaan, Tangibility Asset

Sumber: Hasil Pengolahan Data SPSS ver. 24.0

Nilai F signifikansi $0.000<0.05$ kesimpulan terdapat pengaruh yang signifikan Profitabilitas, Tangibility Asset, Tax Rate, Pertumbuhan Perusahaan, Ukuran Perusahaan.

Hasil Uji Koefisien Korelasi Ganda dan Uji Adjusted $\boldsymbol{R}^{2}$. menunjukkan jika nilai $\mathrm{R}<0,5$ hubungan tersebut lemah. Jika nilai $\mathrm{R}=0,5$ hubungan tersebut sedang. Jika nilai $\mathrm{R}>0,5$ hubungan tersebut kuat. Jika nilai R.> 0,5 menandakan bahwa hubungan tersebut kuat. 
Tabel 10. Hasil Uji Koefisien Korelasi Ganda Model Summary ${ }^{\mathrm{b}}$

\begin{tabular}{ccr}
\hline Model & $\mathrm{R}$ & Adjusted R Square \\
1 & $.392^{\mathrm{a}}$ & 0.129 \\
\hline a. Predictors: (Constant), Ukuran Perusahaan, Tangibility Asset, Tax \\
rate, Pertumbuhan Perusahaan, Profitabilitas. \\
b. Dependent Variable: Kebijakan Utang \\
Sumber: Hasil Pengolahan Data SPSS ver. 24.0
\end{tabular}

Diperoleh nilai R 0.392 menunjukkan hubungan korelasi yang lemah antara variabel independen Profitabilitas, Tangibility Asset, Tax Rate, pertumbuhan Perusahaan,Ukuran Perusahaan dengan variabel dependen Kebijakan Utang. Nilai adjusted $R^{2}$ yang mendekati satu menunjukkan semakin mampu untuk menjelaskan variabel dependen.Hasil Uji adjusted $R^{2} 0.129$,disimpulkan bahwa sisanya $87.1 \%(100 \%$ - 12.9\%) dijelaskan oleh variabel lain di luar penelitian ini.

\section{PENUTUP}

Simpulan. Hasil uji t: Profitabilitas berpengaruh negatif signifikan terhadap Kebijakan Utang,Tangibility Assetberpengaruh positif tidak signifikan terhadap Kebijakan Utang,Tax Rateberpengaruh positif tidak signifikan terhadap Kebijakan Utang, Pertumbuhan Perusahaan ber pengaruh positif tidak signifkan terhadap Kebijakan Utang,Ukuran Perusahan berpengaruh positif signifikan terhadap Kebijakan Utang. Hasil nilai $\mathrm{F}$ signifikansi 0.000, maka berpengaruh signifikan secara bersama terhadap Kebijakan Utang.Nilai adjusted $\mathrm{R}^{2} 0.129$ berarti hanya $12.9 \%$ sedangkan sisanya $87.1 \%$ diperoleh dari variabel lain.

Saran. Melakukan penelitian pada semua sektor perusahaan, tidak terbatas pada sektor manufaktur saja.Menambahkan beberapa jumlah variabel independen yang akan digunakan dalam penelitian selanjutnya seperti Kepemilikan Menajerial, Free Cash flow, Kepemilikan Institusional, Non debt tax shield dan beberapa variabel pengukuran yang lain. Menggunakan data dengan periode yang lebih panjang untuk mendapatkan hasil pengukuran yang lebih valid.

\section{DAFTAR RUJUKAN}

Fahmi, Irfam.(2011). Analisis laporan keuangan. Edisi ketiga. Bandung: Alfabeta, Harahap.

Geovana, Rosella selvilita. (2015). "Pengaruh Growth Sales, Profitabilitas, Operating Leverage dan Tax rate terhadap Kebijakan Utang". Jurnal ilmu \& riset akuntansi, 4 (4), 1-15.

Gitman, Lawrence J and Chad J. Zutter. (2012). Principle of Managerial Finance, Thirteenth Edition. United States: Pearson Education.

Godfrey, Jaynre et all.(2010). Accounting theory, 7th edition Asia: John Wiley \& Sons. 
Ghozali, Imam. (2016). Aplikasi Analisis Multivariete dengan Program IBM SPSS 23. Edisi 8, Penerbit Universitas Diponegoro, Semarang.

Hardiningsih, Pancawati dan Oktaviani, Rachmawati Meita. (2012). "Determinan Kebijakan Utang. Dinamika Akuntansi, Keuangan, dan Perbankan". Jurnal Akuntansi, 1 (1), 11-24.

Harjito, D. Agus dan Nurfauziah. (2006). "Hubungan Kebijakan Utang, insider Ownership dan Kebijakan Dividen Dalam Mekanisme Pengawasan Masalah Agensi di Indonesia”. Jurnal Akuntansi dan Auditing Indonesia, 10 (2), 121-135

Hendra.(2014). The influence of growth, tangibility, firm size, business risk, liquidity, profitability, corporate tax rate, and non debt tax shield torward debt policy on food and beverages. ". Jurnal Akuntansi dan Auditing Indonesia, 16 (1), 111-130.

Kieso, Donald E., Jerry J. Weygandt, dan Terry D. Warfield. (2011). Intermediate Accounting.IFRS Edition. Vol 1. USA: Wiley.

Margaretha, Farah. (2014). "Determinants of Debt Policy in Indonesia's Public Company”. Jurnal Bisnis dan Akuntansi. 3 (2), 10-16.

Masdupi. (2005). "Analisis Dampak struktur kepemilikan pada Kebijakan Hutang dalam Mengontrol Konflik Keagenan”. Jurnal Ekonomi Bisnis. 20 (1), 56-69.

Muslida Dewi Yuniarti. (2013). "Pengaruh kepemilkan Manajerial, Dividen, Profitabilitas dan Struktur Asset Terhadap Kebijakan Utang”. Accounting Analysis Journal. 2 (4), 447-454.

Muslim Mahmudin. (2015). "Pengaruh firm size, growth, tangibility, non debt tax shield, dan profitability terhadap leverage pada perusahan wholesale dan retail trade". Jurnal bisnis dan akuntansi. 17 (1a), 1-8.

Oyong Lisa, R.R. (2012). "Asimetri Informasi Dan Manajemen Laba: Suatu Tinjauan Dalam Hubungan Keagenan”. Jurnal Wiga. 2 (1), 42-49.

Permanasari, Meiryana Soraya. (2017). "Faktor-faktor yang Mempengaruhi Kebijakan Utang perusahaan non keuangan publik". Jurnal Akuntansi, 19 (1), 103-116

Rahmawati, Suparno, Yacob, dan Qomariyah, Nurul. (2006). "Pengaruh Asimetri Informasi Terhadap Praktik Manajemen Laba pada Perusahaan Perbankan Publik Yang Terdaftar Di Bursa Efek Jakarta”. Simposium Nasional Akuntansi VI Padang. 9, 1-28.

Ross, Stephen A., Westerfield, Randolph dan Jordan, Bradford D. (2010). Fundamentals of Corporate Finance. Ninth Edition. New York : McGraw Hill.

Santoso, Singgih. (2015). Menguasai Statistik dengan SPSS 24. , Penerbit PT.Elek Media Komputer, Jakarta.

Sari, Lia. (2012). "engaruh Karakteristik Perusahaan Terhadap Tingkat Utangnya”. Jurnal Ilmiah, 5 (1), 20-29.

Steven dan Lina. (2011). "Faktor-faktor yang Mempengaruhi Kebijakan Utang manufaktur”. Jurnal bisnis dan akuntansi, 13 (3), 163-181.

Sudiyanto, Bambang dan Septavia M.sari. (2013). "Determinants of debt policy: An Emperical Studying Indonesia Stock Exchange”. Educational Research, 4 (1), PP. 98-108.

Surya, Dennys dan Rahayuningsih, Deasy Ariyanti. (2012). "Faktor-Faktor yang Mempengaruhi Kebijakan Utang Perusahaan Non Keuangan yang Terdaftar dalam Bursa Efek Indonesia”. Jurnal Bisnis dan Akuntansi. 4 (3), 213-225. 
Yap Steven. (2016). "Pengaruh Karakteristik Perusahaan, Rasio keuangan, Corporate Tax Rate dan Non debt tax shield terhadap Kebijakan Utang pada perusahaan food and beverages". Jurnal bisnis dan akuntansi. 18 (2), 176-186.

Yeniatie dan Destriana, Nicken. (2010). "Faktor-Faktor yang Mempengaruhi Kebijakan Utang pada Perusahaan Nonkeuangan yang Terdaftar di Busa Efek Indonesia”. Jurnal Bisnis dan Akuntansi. 12 (1), 1-16.

Yuniarti, Ahadiyah Muslida Dewi. (2013). "Pengaruh Kepemilikan Manajerial, Dividen, Profitabilitas Dan Struktur Aset Terhadap Kebijakan Utang”. Accounting Analysis Journal, 2 (4), 447-454.

www.bi.go.id

www.idx.co.id 